\title{
Vernacular Architecture
}

” Towards a Sust

Editors

C. Mileto

F. Vegas

L. García

V. Cristini

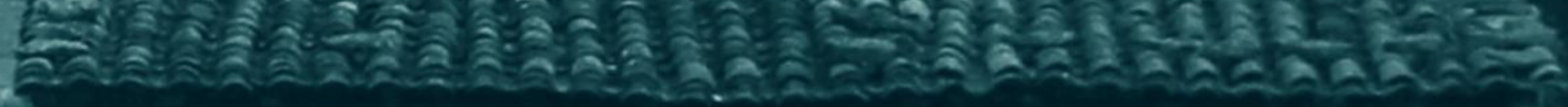
,

1
8
28
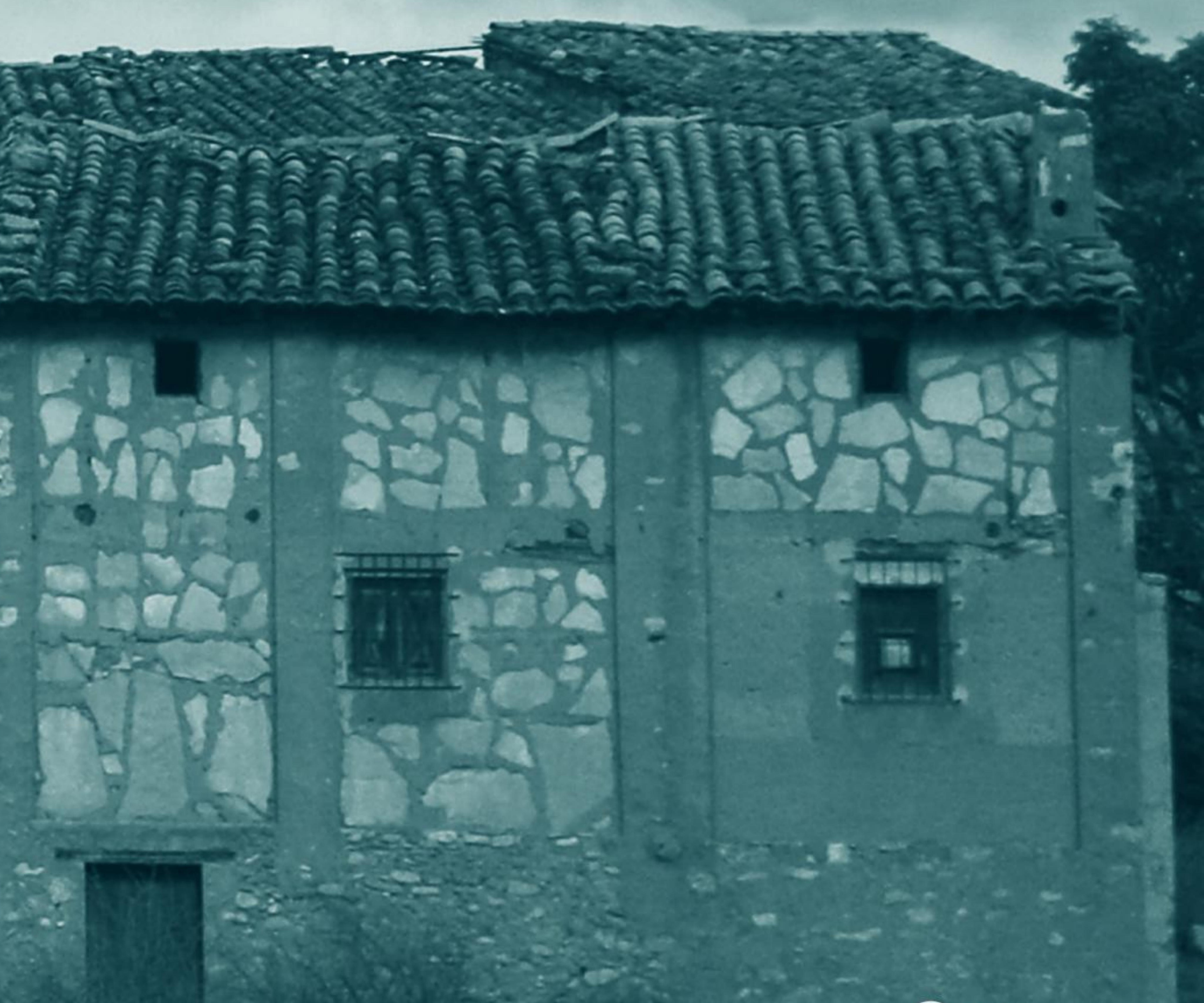

3

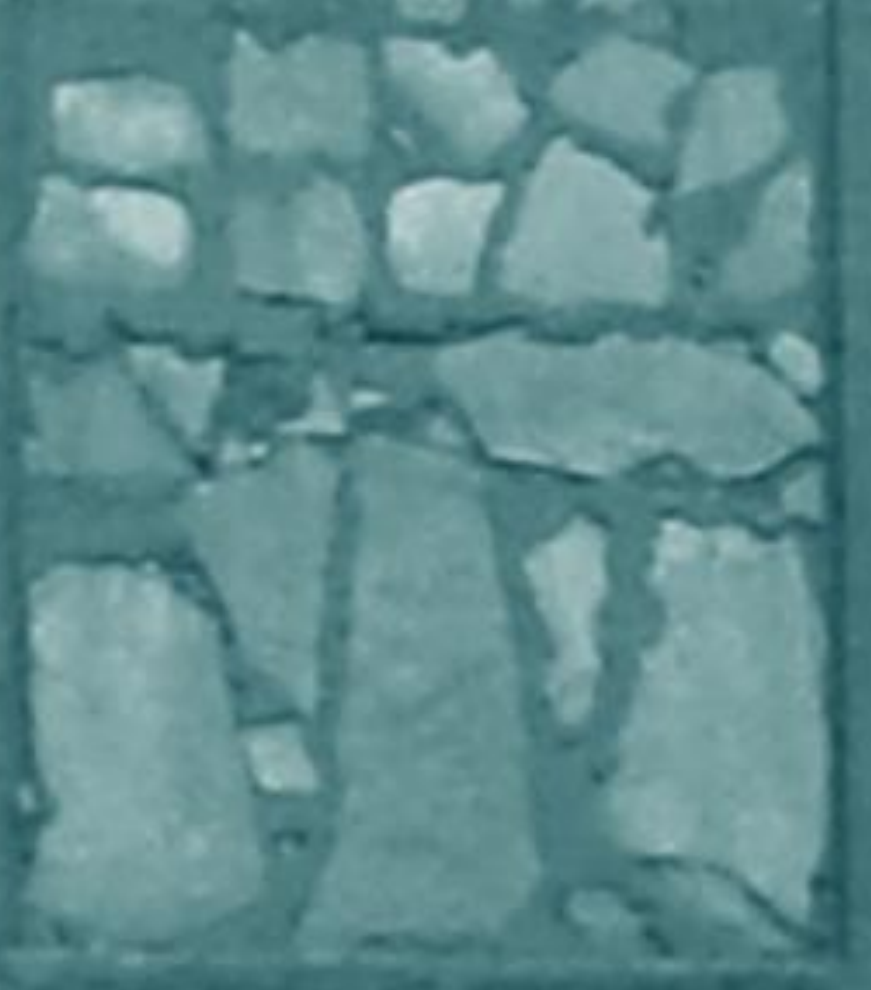




\section{Vernacular Architecture: Towards a Sustainable Future}

Editors

C. Mileto, F. Vegas, L. García Soriano \& V. Cristini

Universitat Politècnica de València, Spain

\section{CRC CRC Press}


Cover photo: Vernacular dwellings at Rincón de Ademuz (Valencia). Picture by Vegas \& Mileto

CRC Press/Balkema is an imprint of the Taylor \& Francis Group, an informa business

C 2015 Taylor \& Francis Group, London, UK

Typeset by V Publishing Solutions Pvt Ltd., Chennai, India

Printed and bound in Great Britain by CPI Group (UK) Ltd, Croydon, CR0 4YY

All rights reserved. No part of this publication or the information contained herein may be reproduced, stored in a retrieval system, or transmitted in any form or by any means, electronic, mechanical, by photocopying, recording or otherwise, without written prior permission from the publisher.

Although all care is taken to ensure integrity and the quality of this publication and the information herein, no responsibility is assumed by the publishers nor the author for any damage to the property or persons as a result of operation or use of this publication and/or the information contained herein.

Published by: CRC Press/Balkema

P.O. Box 11320, 2301 EH Leiden, The Netherlands

e-mail: Pub.NL@taylorandfrancis.com

www.crcpress.com - www.taylorandfrancis.com

ISBN: 978-1-138-02682-7 (Hbk + CD-ROM)

ISBN: 978-1-315-73690-7 (eBook PDF) 


\section{Table of contents}

Preface

Organization and committees

$\mathrm{xV}$

Conference support

\section{Plenary lectures}

Vernacular architecture and sustainability: Two or three lessons...

M. Vellinga

Vernacular architecture in the modern concept of cultural heritage

J.M. Ballester

\section{Lectures}

Conservation of morphological characters as an approach to thermal comfort

A.R. Abd Elrady \& M.H. Hassan

Domes of adobe and stone on the rural architecture of centre of Castilla y León (Spain)

O. Abril \& F. Lasheras

Vernacular heritage solutions for sustainable architecture: The Phlegraean islands

M. Achenza, I. Giovagnorio \& L. Cannas

Approaches to nature in Iranian traditional houses in terms of environmental sustainability

S. Adeli \& M. Abbasi

Conservation of the vernacular heritage in the villages of Bursa, Turkey

Z. Ahunbay, T. Ayranclar, A. Polat \& A. Uray

Láguena, a roofing technique in Campo de Cartagena, Spain

Í. Almela \& L. Martinez

Understanding matter to think and build differently: The amàco project

N. Álvarez, R. Anger, M.M. Bisiaux, H. Houben \& L. Fontaine

Project proposal for the urban redevelopment of Oia, the sunset town

M. Antonelli, C. Crescenzi \& V. Grillo

Perishable materials architectures in Northern Italy (from Roman times to nowadays)

A. Antonini

Qualitative criteria for defining the safety analysis of Ottoman bath structures

K. Apak

The habitat of transhumant shepherds at Mgoun Valley, High Atlas (Morocco)

The construction project of the Moklen ethnic house, Sea Gypsy architecture in Southern Thailand

M. Attavanich \& H. Kobayashi

Sustainability in Saudi vernacular built environment: The case of Al-Ahsa 
Vernacular houses of Datca Peninsula: Architectural typology and its sustainability

O.B. Avsar

Vernacular architecture in Saudi Arabia: Revival of displaced traditions

M.O. Babsail \& J. Al-Qawasmi

Jordanian vernacular architecture

E. Baglioni

10 -year experience from vernacular architecture to contemporary sustainability

M. Balzani, P. Massai \& L. Rossato

Preservation of vernacular schist masonry farm walls

C.E. Barroso, D. V. Oliveira \& L.F. Ramos

Adapting vernacular architecture: The case of the Singapore Cottage in Melbourne

R. Beeston \& N. Matarredona

Preservation and energy behavior in Aosta Valley's traditional buildings

C. Bionaz

Strategies for energy retrofitting of vernacular architecture of Cabanyal-Canyamelar

J. Blanco, B. Serrano, L. Ortega \& L. Soto

Straw as construction material for sustainable buildings: Life Cycle Assessment

of a post-earthquake reconstruction

A. Bonoli, S. Rizzo \& C. Chiavetta

Studies on vernacular architecture in Italy: The experience of G. Ciribini (1913-1990)

D. Bosia

Guidelines for rehabilitation of vernacular architecture

D. Bosia \& L. Savio

Perceptions of vernacular architecture

G. Bosman \& C. Whitfield

\section{A. Bouchair}

The Kasbah of Dellys in Algeria, revitalization and conservation through tourism

D. Boussaa

Restoration and rehabilitation in Palestine: Hosh el Etem in the historic centre of Birzeit

K. Bshara, J. Barlet \& R. Salem

Study of the behaviour of agglomerates with lime: Mortars, concretes, soils

M. Camprubi, M. Cònsola \& X. Vallory

Life Cycle Assessment as a means to grow awareness on the environmental impact of conservation

C. Careccia \& M. D'Incognito

Open Tools applied to low-tech curved roofings, Elche \& Muchamiel, Spain

J. Carrasco, J. Bermejo, P. Ferrando, A. Enguita \& J. Toledo

Via Traiana-an ancient route for contemporary territorial development

G. Ceraudo \& L. Salierno

Traditional housing in Calabria: Past and present

R. Chimirri

VerSus project: Lessons from vernacular heritage for sustainable architecture

Vernacular seismic culture in Portugal: On-going research

M. Correia, G.D. Carlos, D. Viana \& F. Gomes

The application of traditional "tube house" in water revitalization

M. Dao Le Hong 
Sustainable living: Environmental integration in 15 vernacular Spanish houses

M. de Luxán, G. Gómez \& E. Román

Structural analysis of traditional gypsum walls from the $12^{\text {th }}$ century in Spain

B. de Miguel \& G. Pardo

Guastavino vaulting: Adaptation of Spanish vernacular architecture in the USA

B. de Miguel, K. Diebolt \& G. Pardo

Log driving on the Turia river: Spain: Provisional structures

M. Diodato, P. Privitera \& S. García Sáez

Local seismic culture and earthquake-resistant devices: Case study of Casa Baraccata

L. Dipasquale, D. Omar Sidik \& S. Mecca

The Sado's estuary huts, vernacular forms and ways of living the space

M. dos Santos

Vernacular morphology as a preventive solution of local seismic culture

G.D. Carlos, M. Correia, D. L. Viana \& F. Gomes

Aisle-truss houses of Northern Jutland: Strategies for sustainable design

B.T. Eybye

B. Fakharian

Primary energy and $\mathrm{CO}_{2}$ emissions in vernacular as compared to conventional architecture

M. Fernández, A. Martínez, A. Alonso \& V. Llopis

Features and conservation issues of stone houses in the inland Abruzzo

D. Fiorani

Renewable energy sources for rural architecture in fragile landscapes

G. Franco \& S.F. Musso

Thermal zoning and natural ventilation in vernacular Anatolian settlements

T. Frank, C. Luke \& C. Roosevelt

The Porticoes of Bologna: Methodology for sustainable restoration

C. Galli \& F. Naldi

Lessons from the vernacular architecture in Sierra Mágina, Jaén

J. García \& C. López

Study and preservation of a fresquera

M. Genis-Vinyals, J. Planelles-Salvans, C. Sanmartí, O. Palou,

$R$. Lacuesta \& D. Sancho

Climatic analysis methodology of vernacular architecture

I.J. Gil, M.M. Barbero \& L. Maldonado

Architecture by the vineyards: The case of Caudete de las Fuentes

R. Giménez \& S. Tomás

Local Seismic Culture in Portugal: Melides dwellings, a reactive approach case study

F. Gomes, M. Correia, G.D. Carlos \& D. Viana

Continuing Tradition: Farms in the northeast region of Portugal

$J$. Gonçalves, R. Mateus \& T. Ferreira

Ancient techniques, new architecture

A. González \& M.C. Lazzarini

S. Jackson-Stepowski

Organic architecture based on vernacular heritage: The CIRCE building

P. Jebens-Zirkel \& M. Figols González 
A relation between the passive design and local community in Rincón de Ademuz, Spain

W. $J i$

Methodology to characterize the use of pine needles in adobes of Chiapas, Mexico

N.J. Jiménez, L.F. Guerrero \& F. Jové

Bioclimatic analysis for a vernacular Guarani house

M.A. Jiménez \& L.E. Gonçalves

Teaching the vernacular: Lessons for a local sustainable architecture in Chile

N. Jorquera

A typical island habitat: The baracca of Carloforte

F. Juan-Vidal \& A. Merlo

Transformation between corbelling and lintel: Abrigo and Espigueiro

B. Juvanec

Exploration of sustainable reform on urban villages in Zhangjiagang

X. Kanda \& S. Yong

Sustainability of the thatched house in Nadasyo village in Fukui prefecture, Japan

H. Kobayashi, K. Fukui \& H. Mitani

Gypsum quarries used in Valencian architecture: Past, present and future

V. La Spina, L. García Soriano, C. Mileto \& F. Vegas

Historical centers in Sabine, Italy: Links between architecture and environment

S. Landi

Sustainability notions in vernacular architecture of Choapa Valley

M.L. Lobos, N. Jorquera \& F. Pfenniger

Form and materiality in contemporary Southern Moroccan architecture

J.M. López-Osorio, T. García, E. España \& D. Arredondo

Habitat and vernacular architecture of the Sama Range (Bolivia)

J.M. López-Osorio, M. Ventura, M. Alves de Freitas \& P. Vásquez

Architectures in transformation in Perú: Tradition and modernity

J.M. López-Osorio, G. Ríos \& U. Martín

Sustainable architecture in the traditional rural environment: Moratalla

Gypsum and giant canes in the Sicilian traditional architecture

A. Mami

The ornament of the south facing turret and the Islamic wall fragment, Valencia (Spain)

J. March-Estrada, S. Martínez, S. Kröner \& X. Mas-Barberà

A. Martínez, V. Blanca \& F. Aranda

The B4U assessment tool for urban regeneration projects and its Profit indicators

C. Mateo \& A. Fernández

The impact of using triangular shapes on the Nubian and Najdi architectural composition

N. Mohamed Gharib \& W.M.H. Mohamed

French vernacular heritage to inspire a new sustainable architecture

S. Moriset, N. Sánchez \& E. Sevillano

L. Mormino

Restoration of the dry stone masonry channel at the Monastery of L'Estany

A.J. Morros \& B.C. Puigferrat 
Urban and architectural features of traditional built environment

of Farasan Islands, Saudi Arabia

H.A. Mortada \& M. Baleha

The impact of updates the Nubian architecture on internal ventilation

H.S. Mostafa \& A.R. Abd Elrady

How to understand vernacular sustainability of earthen architecture only considering

the inventory and technical knowledge?

I. Moulis, M. Jamin \& A. Marcom

"Peasant plaster": From rocks to decorated ornaments

I. Moulis \& P. Bertone

Campania Felix, smaller towns, vernacular and sustainability

G. Multari

"Guidelines" for sustainable rehabilitation of the rural architecture

S.F. Musso \& G. Franco

The phenomenon of tourism: Redefining architecture and landscape

Spatial transformation of traditional garden houses in Hue Citadel, Vietnam

N.T. Nguyen \& H. Kobayashi

A sustainable project collaborating with inhabitants to build gangi

(wooden arcades)

S. Nishimura, S. Terada \& S. Boda

A. Novák \& P. Medgyasszay

Diagonal tests on adobe panels reinforced by traditional and innovative

anti-seismic retrofits

D. Omar, F. Ridolfi, L. Rovero \& U. Tonietti

Sustainability evaluation of materials in architecture

J. Orozco \& V. Climent

Resilience and intangible heritage of vernacular architecture

Peri urban agriculture as a new strategy of urban development: A case study in Cenaia, Pisa B. Özel, S. Mecca, F.M. Lorusso \& L. Dipasquale

Self-sustaining vernacular habitats: The case study of Medina of Chefchaouen

B. Özel, L. Dipasquale \& S. Mecca

A. Pane \& C.C. Battaglia

The traditional architecture of Cabanyal neighborhood, a sustainable heritage

R.M. Pastor \& J.L. Higón

Energy efficiency of listed buildings in L'Eixample District in Valencia

A. Pérez \& A. Guardiola

Studies of Persian vernacular heritage and its building identity

S. Petralla

Examination and assessment of the environmental characteristics of vernacular rural settlements: Three case studies in Cyprus

M. Philokyprou, A. Savvides, A. Michael \& E. Malaktou

Hassan Fathy in New Bariz, vernacular heritage and design process

A. Picone 
Vernacular architecture in Campania Felix: Values and conservation problems

R. Picone

Preliminary studies on traditional timber roof structures in Gjirokastra, Albania

F. Pompejano \& K. Merxhani

Solar radiation influence on pre-modern openings features: La Coruña and Valletta

P. Privitera, M. Diodato \& S. García Sáez

The energy management of the pre-modern expansion: The study case

of Russafa (Valencia, Spain)

I. Puig, F. Juan-Vidal, B. Serrano \& C. Jimenez

Identification and analysis of passive energy resources applied in constructions

of "La Mancha" region, Spain

J.R. Ruiz-Checa, V. Cristini, J.L. Higón \& J.A. López

Historical "ghost" towns: Sustainable conservation issues in Southern Italy

V. Russo

The walls of the Medieval new town of Vertavillo, Palencia (Spain)

A. Sainz, J.L. Sáinz \& F. Jové

Vernacular settlements in Peneda and Laboreiro, Portugal: Spatial organisation

G. Sousa \& F. Gomes

Traditional techniques and materials in the Amalfi Coast: The Norman Tower in Maiori

A. Spinosa, L. Veronese \& S. Borea

Restoration informed by archaeology of a Mexican-American adobe ranch house

I.R. Stiegler, S. Van Wormer \& S.D. Walter

Moravian master builders and their contribution to sustainability

Z. Syrová \& J. Syrový

Reading vernacular structural system features of Soma-Darkale settlement

691

M. Tanac \& O. Yilmaz

Sustainability of compression layers: Timber and concrete compared

S. Tomás, M. Diodato, F. Vegas, C. Mileto \& R. Giménez

The house as a moving story: An ethnography of Andean domestic architecture

J. Tomasi

The transhumance architecture: Handing down seismic knowledge while migrating

S. Tonna, C. Chesi \& L. Marino

Cultural influences in Mexican vernacular architecture

G. Torres

\section{T. Tsukidate}

Discordant goals in Alpine rural heritage restoration: Discussion and proposals

A. Turato \& V. Ferrario

D. Ulivieri

$0 \mathrm{~km}$ conservation

F. Vegas \& C. Mileto

Gypsum vaults in Sicily as a reinterpretation of Catalan vaults

R. Verga

I. Vestergaard 
Mechanism of traditional screen in the architecture of Louis I. Kahn

C.M. Vidal, I.E. Vidal \& M.T. Palomares

The Ruka Mapuche: Clues for a sustainable architecture in southern Chile?

C.J. Whitman, G. Armijo P. \& N.J. Turnbull

Conservation and management for Fishing Town, a Chinese vernacular heritage site

G. Yuan, Y. Yifeng \& S. Yong

Conservation and sustainable development of China vernacular architecture heritage:

Case study on Hanling and Shuimotou

C. Yue \& S. Yong

Research of the values of vernacular architecture heritage concept in China's rapid urbanization Yuedi

Author index 


\title{
Local seismic culture and earthquake-resistant devices: Case study of Casa Baraccata
}

\author{
L. Dipasquale, D. Omar Sidik \& S. Mecca \\ University of Florence, DIDA Department of Architecture, INN-LINKS Research Centre, Florence, Italy
}

\begin{abstract}
In the contexts of high seismic activity, such as the Mediterranean area, many local communities have developed strategies for managing such a risk, adapting all available resources for creating earthquake-resistant rules, shaping not just a particular building culture, but a complex local seismic culture: earthquakes become part of the experience of the community and part of the collective identity of the group, that joins together the efforts to achieve the stability of the building environment. The paper investigates on and analyses the contribution of Mediterranean local building culture in the strategies of defence against earthquakes, through their conditions, logic and specific devices. This paper presents those technical building devices, which are strictly connected to the local seismic culture, and describes in detail the techniques that use timber framed structure, coupled with earthen and stone masonry, to absorb loads horizontally.
\end{abstract}

\section{INTRODUCTION}

This paper investigates the contribution of indigenous and vernacular cultures in the strategies of defence against earthquakes, through their conditions, logic and specific devices. The starting point is the fact that many of the current findings on the reinforcement of masonry and earthen buildings have interesting and ingenious precedents in the traditional techniques of the cultures in the Mediterranean, Balkans, Middle and Far fast. While maintaining a poor local language and tacit building rules, many of these architectures have developed the ability to adapt to the surrounding environment and live with the inherent risk of earthquakes. The necessity to rediscover the rulesof-the-art and the techniques used in historical buildings have been acknowledged in the recent scientific debate and a deeper understanding of the peculiarities of such artefacts is considered of fundamental importance for the research of compatible and effective procedures, for the seismic retrofitting of historical buildings.

\section{BACKGROUND AND RESEARCH METHOD}

In regions affected by frequent and high intensity earthquakes, local communities have developed strategies to protect themselves from the risk, such as building systems or specific devices, designed to reduce the vulnerability of their building habitats.
The extraordinary quality of some of the practices and constructive traditional advice, and their relevance over times and during seismic phenomenon, prompt us to investigate these techniques, in order to understand them and codify the tacit rules to regulate local earthquake-resistant systems.

INN-LINK-S (Innovation of Local and Indigenous Knowledge Systems) Research Centre defines its own research on local knowledge systems as strategic element in the process of local sustainable progress, able to improve the lives of people. According to a systemic approach, we believe that the knowledge of material factors and immaterial ones have to be integrated to codify the tacit variables of a local building culture, and to transmit this knowledge to the experts, as a resource for restoration and contemporary constructions, as well as to the local communities, that must take an active role in the transformation of their environment. In the study of the local seismic culture in vernacular architecture our mission is to define the instruments of analysis, codify the tacit rules that determine the technical devices that have been developed over centuries of experience by the communities, improve and innovate them, and disseminate this knowledge in order to reduce the vernacular architecture vulnerabilities (Dipasquale et al, 2011).

In this paper we investigate the concept of local seismic cultures and we identify some of the strategies developed in the Mediterranean vernacular architecture to protect buildings against earthquakes. Masonry reinforced with Timber structures is selected as a representative typology for 
seismic building techniques. The case-study of "casa baraccata", which arose in Calabria (southern Italy) following the 1783 earthquake, will be deeper described and compared to others timber framed structures used to reinforce masonry in seismic Mediterranean areas.

The aim of this contribution is to better understand and enhance the earthquake-resistant contribution of traditional devices in order to identify suitable methods for protecting and reinforcing buildings against earthquakes, geared as closely as possible to the specific features of ancient buildings in the local area.

\section{LOCAL SEISMIC CULTURES}

In a given society, the existence of a local building culture implies the development of a process of awareness and sedimentation of knowledge on the tacit rules that define the constructive systems. A seismic culture can be described as the entirety of knowledge, both pragmatic and theoretical, that has built up in a community exposed to seismic risks through time (Homan et al., 2001). The local seismic cultures include the earthquake-resistant regulations which have not been formally laid out in written code but which are still visible in the building characteristics, in the choice of the site and in the general layout of the territory (Ferrigni, 2007).

The origins and persistence of a local seismic culture can be determinate both by the scale of intensity and the frequency with which the earthquakes occur, and the economic and social conditions, including resource availability and the cultural traditions (Ferrigni et al, 2005). The ancient builders used all the well-known constructive criteria and devices to build houses able to resist earthquakes; perfecting them with time and experience, and comparing the performance of these systems with respect to the effects caused by earthquakes. In this way a process of technical evolution by experimental testing has been developed, that is based on the direct observation of the real behaviour, following telluric forces.

However, in areas where violent earthquakes have very long return periods (as for example in Italy), local earthquake-resistant devices are implemented in the period following the event, but the seismic culture becomes more and more weak over the years, ending in the the loss of the risk awareness by the community.

Earthquake-resistant vernacular reinforcements are numerous, and in a lot of instances, depend on available materials, local building cultures and the skills of the builders. Recurring defence mechanisms consist of: metal lacing systems, buttresses, large section walls, reinforcing arches, technical solutions with the purpose of maintaining the box-like behaviour.
Amongst the ancient cultures the Cretan (2000 1200 BC) and Mycenaean (in the fourteenth century BC) had developed a great sensitivity towards earthquakes. Archaeological excavations have revealed some of the devices used in the ancient buildings. Amongst the remains there exists masonry composed of limestone and gypsum stones, where some of stone elements are placed systematically in the direction perpendicular to the wall. The walls intersect each other tightly and, always crossing at right angles, form dense rectangular mesh networks. This planimetric configuration allows the creation of patterns capable of withstanding strict regimes of dynamic stress. In addition, the work of archaeologists have unveiled inside the large stone blocks, the housings of large pins crossing the rocks to accommodate wooden connecting elements, with the purpose to keep the various blocks connected and to give a strong plasticity to the whole structure.

In ancient Roman building traditions, rows of bricks were set down horizontally through the conglomerate wall section, functioning not only to connect and reinforce, but at the same time serving to interrupt the possible spreading of cracks. This technique is still visible in many walls of the Italian historic cities.

In seismic regions where stone, earth or bricks masonry is the prevalent building technique, the most frequent prevention and/or reinforcement measures consist of adopting the mechanism of mutual contrast between (or part of) the buildings to counteract horizontal forces. (Pierotti et al, 2001).

Some traditional devices used to counteract horizontal forces are: spurs, buttress, wall braces, stairways, loggias, open gallery, and contrast arches which are often located at floor beams level (fig. 1).

Other preventive measures in the history of local building cultures relate to the implementation of design criteria for settlements. An Italian example can be seen in the cities located in the South-East of Sicily, rebuilt after the 1693 earthquake. This catastrophic event completely destroyed sixty cities, leaving others badly damaged.

Reconstruction began almost immediately after the earthquake: the new urban plans are based on linear and reticular patterns, very different from the previous organic medieval schemes; streets are larger with ample spaces, such as squares, designed in order to create outdoor safe zones in case of earthquake. The new buildings present as a rule a stone load bearing walls separated by 4 to $6 \mathrm{~m}$, and two floors. The ground floor is generally used as a storehouse, stable or service room. It is covered by a vaulted structure made of squared stones and mortar (contributing to lowering the gravitational centre of the building) while the intermediate one present a lighter wooden framed floor. 

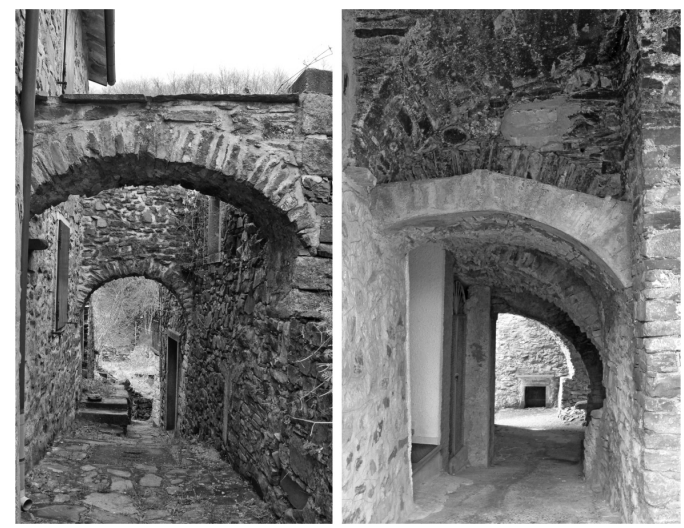

Figure 1. Traditional devices used to counteract horizontal forces in Lunigiana, Italy (L. Dipasquale).

Another prime example of urban anti-seismic reconstruction design is the "Baixa Pombalina", the historical downtown of Lisbon, rebuilt after the disastrous 1755 earthquake into sixty blocks, mostly rectangular, consisting of seven buildings each. The buildings of each block are constructed side by side, sharing the same gable walls (called gaiola). The rectangular blocks were designed to form an orthogonal grid of streets; the width of the main streets was approximately equal to the height of the façade, being constant for all the buildings.

\section{TIMBER FRAME AS EARTHQUAKE RESISTANT REINFORCEMENT}

In areas where earthquakes are endemic, a recurring strategy is the use of wooden elements as devices to improve the earthquake-resistant performance of the building, and also to increase the structural behaviour of the stone, adobe or bricks masonries.

The great elastic properties of wood, its characteristics of flexibility, lightness and deformability without reaching the breaking point, offers good resistance capacity against horizontal loads, and enables the dissipation of substantial amounts of energy. Moreover, timber elements divide the structure into sections, which prevent the spread of cracks occurring in portions of the masonry.

There are many past examples that show how traditional wooden structures have demonstrated good performance during seismic events. By creating horizontal and vertical connections, wooden devices applied to structures with good compression behaviour (such as stone, adobe or brick masonry) can improve the resistance to shearing, bending and torsion forces. There can be various uses of wood as earthquake-proof reinforcement
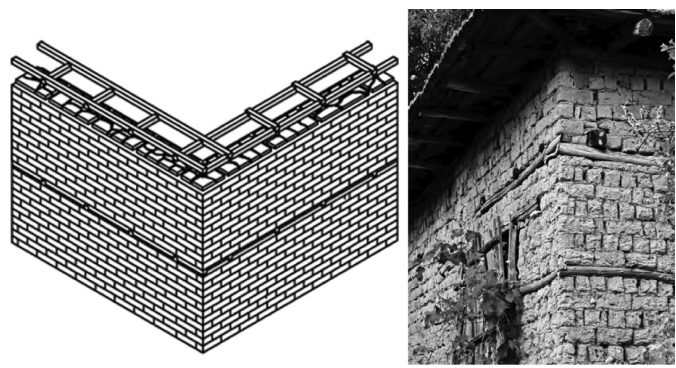

Figure 2. Timber hooping. The building system scheme; example of a building in Antartiko, Greece. Drawing: D. Omar Sidik. Photo: S. Mecca.
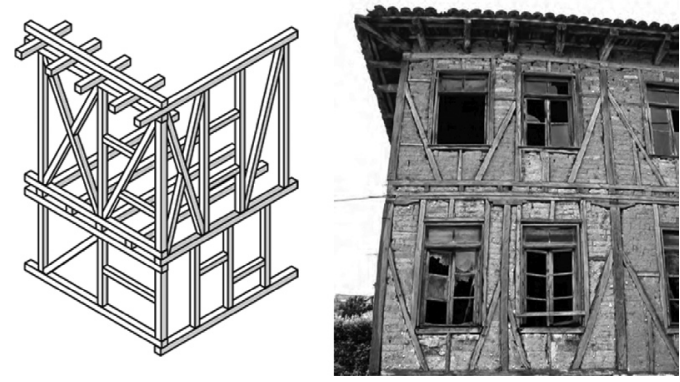

Figure 3. Timber frame System. The building system scheme; example of a building in Kastaneri, Greece. Drawing: D. Omar Sidik. Photo: S. Mecca.

material, but two main categories can be found: the hooping and the frame systems (Figs. 2-3). The first (Fig. 2) provides the arrangement of the circular or square section wooden beams, horizontally disposed within the load-bearing masonry during the construction phase. In many cases two beams are used, one to the inner side of the wall and the other to the outer, connected by transverse wooden pieces. The empty spaces between the beams are filled with fragments of brick or stone. Interlocking systems of nailing's are used for the connections between perpendicular elements. The ring beams can be inserted at the height of the floors, in correspondence to the openings and lintels or regularly distributed along the height of the construction.

The wooden frame system (Fig. 3) is instead articulated in round or square section beams and pillars, and frequently, diagonal bracing elements. The empty spaces defined by the frame are filled with locally available materials (earth, stone or brick).

If the beams are not as long as the entire wall, timbers are connected together through elaborate interlocking systems. In some cases the longitudinal beams are held together in the thickness of the wall by transverse elements that are wedged or nailed, and the corners present additional reinforcement. 


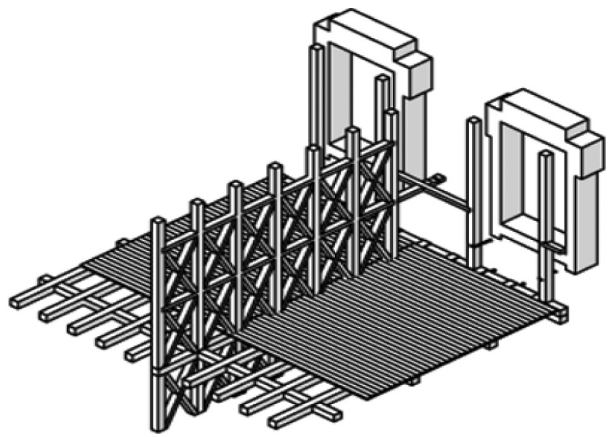

Figure 4. Gaiola building system. Credits: D. Omar Sidik.

One of the most ancient examples in Italy of timber-frame buildings techniques is the opus craticium by Vitruvius, today visible in some of the surviving houses of the archaeological sites of Herculaneum and Pompei. The opus craticium, was largely diffused in the Roman Provinces, and later developed in different ways in a large number of Mediterranean and European areas.

Relevant examples of timber frame structures together with masonry can be found in Turkey, in Greece and parts of Eastern Europe. In these countries common traditional buildings techniques are based on the use of masonry laced bearing wall constructions on the ground floor level, and lighter infill-frames for the upper stories. The ground floor masonry walls are often laced with horizontal timbers; these elements can be thin timber boards laid into the wall placed so that they overlap at the corners or squared wooden beams.

A very significant example of the use of timber framed structures for masonry anti-seismic rein forcement is the so-called "gaiola" system, diffused in Lisbon after the earthquake of 1755. The technique of Gaiola includes the use of the "Pombalino" wall. This system consists of a set of timber members, embedded along the inner face of the main stone masonry façade wall. The timber elements are made of oak or holm oak squared beams, with a section of $9-12 \mathrm{~cm}^{2}$. The wooden elements of the structure are framed forming a pair of crossing braces, called in Italy St. Andrews Cross and are connected with both the walls and the floors timber beams, forming a cage (gaiola) (Ruggeri et al, 1998, Gulkan, 2004, Paula et al, 2006).

The frame is filled with brick, whole and broken pieces, and stone rubble. The interior walls are covered with plaster, hiding the infill and the timber frame. The building is no more than four storeys high, with masonry arcades at the ground floor level, external structural masonry walls (gaiolas), internal timber-masonry walls (frontais), and internal partition walls (tabiques) (Fig. 4). All these structural elements combined have very good earthquake resistant performances, as many experimental studies have shown.

\section{THE CASE STUDY OF THE "CASA BARACCATA"}

The observation of buildings damage and the recognition of the validity of the traditional techniques led the rebuilding process after the earthquake of Calabria in 1783.

The earthquake that struck Calabria region in 1783 marked an important milestone in the history of the local building culture. The intensity of the shocks and the rapid sequence of the aftershocks (between 5 February and 28 March there have been 5 earthquakes and more than one thousand shocks) caused inestimable damages and more than 50.000 dead. The high vulnerability of the built heritage, combined with the poor construction quality, led to the collapse of most of the buildings in Calabria, located in more than 180 towns, wholly destroyed. After the disaster, the Bourbon government sent out a research team from the Neapolitan Academy of Science and Letters in order to improve the knowledge and the structural aspects of the local constructions. A year after the seismic events a remarkable work, "Istoria de' fenomeni del tremoto avvenuto nelle Calabrie e nel Valdemone nell'anno 1783" (Account of the Effects of the Earthquake in Calabria in 1783) was published by Giovanni Vivenzio. It represents one of the earliest concerted responses to earthquake danger, one that was lauded by early 20 th-century engineers as a practical means of providing safe construction in earthquake countries. The document drew the guidelines to ensure security and stability to the structures in case of earthquake. Observing the survived buildings behaviour it was detected that the structures with wooden connections proved a greater resistance. Therefore the building directives for the construction of new earthquake resistant buildings suggested the employment of an improved building system, inspired from the vernacular technique of casa baraccata (masonry buildings whit a simple timber frame structure), including at the same time some principles of the 1755standard of Lisbon gaiola system.

\subsection{The "casa baraccata" building system}

The structural system of the "casa baraccata", composed of a wooden structure in-filled with cob, adobe and/or stones, was present in central and southern Italy from the fourteenth century. The wooden elastic properties were widely known, however, the timber was used without any particular attention to the join between beams. 


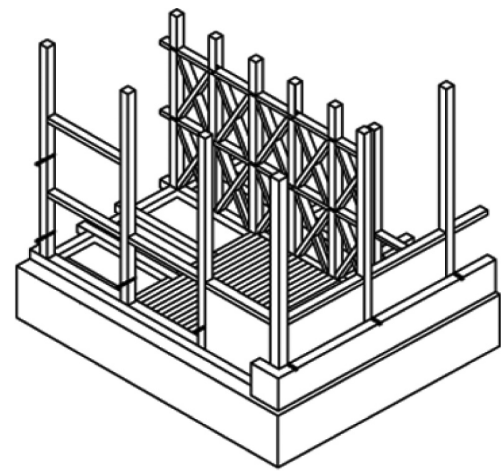

Figure 5. Casa baraccata building system. Credits: D. Omar Sidik.

The term "casa baraccata" originally identified the traditional temporary shack (baracca in Italian) built as shelter immediately after the earthquakes. Historical documents testify the wide usage, and good behaviour of the traditional casa baraccata, diffused in the seventeenth century (Ruggeri, 1988).

The building system designed by Giovanni Vivenzio after the earthquake of 1783 presents a more rigorous architectural scheme where specific devices act to create solid connections and develop a good box-like action between all the elements of the building (Fig. 6). Earthquake resistant buildings should present one or two floors, with a regular and symmetrical plan. The system should consist of timber frame structures with infill stone or adobe (locally called vriesti, bresti or mattunazzu) masonry. The frame elements are covered externally with mortar, thus they are protected from deterioration caused by atmospheric agents and by insects. The external walled structure is made of straight vertical and horizontal pieces, with a square section of $10-12 \mathrm{~cm}$. The internal load bearing walls include sloping timbers as braces giving extra support between horizontal or vertical members of the timber frame. The connections between the wooden beams and pillars should take the form of snaps and rivets (Fig. 5) (Tobriner, 1997). The foundations are made of stone and the cover is a tile pitched roof. The interior walls are often composed of a mesh of interwoven canes and/or branches covered by an earthen plaster, called "incannicciato.

\subsection{Structural behaviour of the "casa baraccata"}

The casa baraccata can be defined as a "dual" construction system, in which the outer walls and the inner wooden frame cooperate to provide a resistant behavior both to vertical loads and horizontal forces. The inner frame is activated during seismic events and provides flexibility to the overall sys-

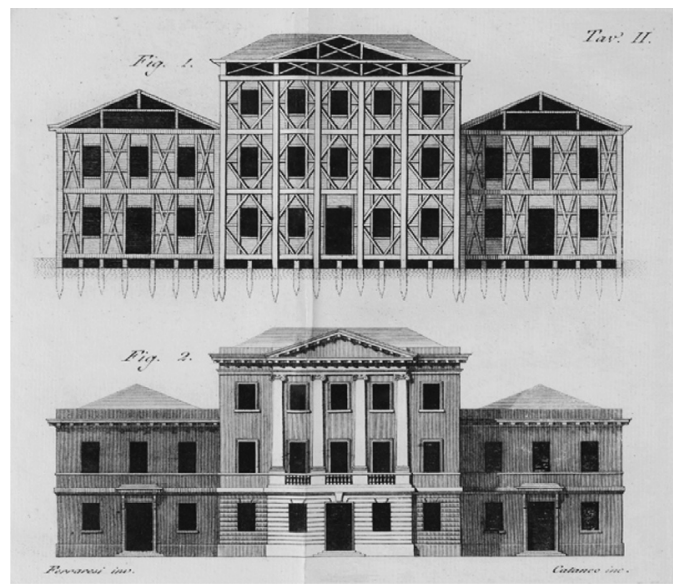

Figure 6. Casa baraccata. Giovanni Vivenzio drawings.

tem. The members of the wooden structure are connected to each other and to the external walls through elements of carpentry and/or metal joints, to create a more homogeneous and continuous structural system. The partition walls, in which the wooden beams are placed to form a St. Andrews Cross, act as stiffening members and provide a further contribution to the resistance against lateral forces (Omar Sidik, 2013).

\subsection{Present and future implementation of "casa baraccata" system}

The good earthquake resistant performance of this system was tested during the earthquakes that struck Calabria in 1905 and 1908, registering a magnitude of 7: the buildings suffered few significant damages and limited portions of masonry collapsed; the majority of collapses were caused by the loss of effectiveness of the connections made by nailing.

In the following decades the "Casa baraccata" system has not been implemented with the rigor and the respect viewed in the extensive literature. Many "casa baraccata" buildings present insecure timber connections; vertical, horizontal and sloping timbers inside the masonry are arranged without logic and rigor. The bad quality of the building system processes applied, in addition to the degradation due to time, cannot ensure the survival of these buildings in the case of earthquake.

In 2013, a research conducted by the Italian National Research Council (CNR-Ivalsa) of San Michele (TN) and the Department of Earth Sciences, University of Calabria (UNICAL), scientifically demonstrated the validity of this building system. They reproduced a 1:1 scale portion of a wall of the bishop house of Mileto (Calabria), 
consisting of masonry reinforced with timber frame, and tested it in a vibrating table, employing a gradually increasing series of alternating movements in both directions.

The seismic performance of the walls proved to be excellent, with a few minor expulsion of masonry, while the timber frames remained almost completely intact. The test confirms the hypothesis that this ancient technique may be favorable applied to modern earthquake resistant buildings, adapting it to the contemporary needs and normative standards. For example, adopting standardized and certified materials, improving joints systems to guarantee a firm connection between the timber elements, adopting adequate connection systems between the timber structure and the masonry, and adopting industrialized production methods.

\section{CONCLUSIONS}

Building knowledge and know how learned and tested over the years in seismic areas have for centuries formed the unwritten earthquakes resistant building codes; these were codified in recommendation and regulation only since the eighteenth century.

In the case of the aftermath of the earthquake of Calabria, practical knowledge arising from vernacular architecture was used to define the earthquake resistant criteria and to support the reconstruction process. The traditional system of "casa baraccata" has emerged as a relevant seismic resistant building technology, which incorporates innovative methods designed to resist seismic forces. Unfortunately, many of the local seismic resistant techniques adopted, including those in Calabria after 1783 , were progressively kept out from the building practices.

One of the missions of the scientific community is to raise awareness that designing buildings with appropriate construction principles and settlement patterns can reduce seismic risk. Over the last decades the culture of reinforced concrete, supported by technical standards and ignoring the traditional materials, has been dominant. However, the improper use of standardized building materials and the hybridization between old and new structural concepts, ignoring the pre-existing structural equilibrium, are not suited for earthquake resistant retrofitting, and can even introduce deep and dangerous alteration to the building. Vernacular architecture requires, therefore, intervention in full respect of the original structural concept, presenting low intrusiveness and, whenever possible, reversibility.

Reducing the vulnerability of ancient buildings, as well as modern buildings, through the lessons of local seismic culture can achieve an appropriate and innovative response to emergencies. Using these lessons from the past, we can even learn something that could help address the severe problems that modern reinforced concrete buildings have manifested after earth-quakes (in Italy for example after the last earthquakes: 2009 in Abruzzo, 2012 in Emilia Romagna).

The awareness of the extraordinary quality of many traditional solutions, and the interest in the preservation of this heritage and the building culture, represents essential achievements through which we can compose models for appropriate effective rehabilitations, future sustainable architectures and settlements. The recognition of local seismic cultures requires a systematic and homogeneous form of cataloguing and archive work, that can used to improve building codes, and to create protocols listing, which can aid technicians to identify suitable methods for protecting and reinforcing buildings against earthquakes, geared as closely as possible to the specific features of ancient buildings in the local area, respecting the original structural concept and, therefore, their authenticity.

\section{REFERENCES}

Dipasquale, L., Jorquera, N. 2011 Learning from local seismic cultures, as a strategy for reducing the risk of cultural heritage. In Mecca, S., Fioravanti, M. The Safeguard of Cultural Heritage: A Challenge From the Past for the Europe of Tomorrow. Firenze: Firenze University Press.

Ferrigni, F. 1997. Local Seismic Culture, Ancient Buildings and Earthquakes, European University. Centre and Council of Europe.

Gulkan, P. Langenbach, R., 2004. The earthquake resistance of traditional timber and masonry dwellings in Turkey. 13th World Conference on Earthquake Engineering Vancouver, B.C., Canada August 1-6, 2004 Paper No. 2297.

Omar Sidik, D. 2013. Presidi antisismici nelle culture costruttive tradizionali. Prime validazioni sperimentali relative all'impiego del legno negli edifici in terra. Unpublished $\mathrm{PhD}$ thesis. Università degli Studi di Firenze.

Paula, R., Cóias, V., 2006. Rehabilitation of Lisbon's old "seismic resistant" timber framed buildings using innovative techniques. International Workshop on "Earthquake Engineering on Timber Structures.

Pierotti, P., Ulivieri, D. 2001. Culture sismiche locali. Pisa: Plus

Ruggeri, N. 1988. Il sistema antisismico borbonico muratura con intelaiatura lignea genesi e sviluppo in Calabria alla ine del '700. Bollettino Ingegneri, 2012, n. 10, pp. 3-14.

Tobriner, S. 1997. La casa baraccata: un sistema antisismico nella Calabria del XVIII secolo. Costruire in laterizio, $n^{\circ} 56$. pp. $110-115$. 